\title{
Partial Freezing as a Means of Preserving Fish Freshness-1 Changes in Free Amino Acids, TMA-N, ATP and Its Related Compounds, and Nucleic Acids during Storage*1
}

\author{
Hitoshi UchiYAMA*2 and Noboru Kato*2 \\ (Received July 4, 1974)
}

\begin{abstract}
In order to develop a storage procedure to be used in place of iced or frozen storage for the preservation of fish freshness, partial freezing for periods of up to 2-3 weeks was examined using sea bass. The criteria for evaluation were made according to the changes in the amounts of free amino acids and trimethylamine nitrogen as well as post-mortem autodegradation of nucleotides and nucleic acids in fish muscle.

The changes in the free amino acids of muscle during storage at $-3^{\circ} \mathrm{C}$ differed significantly from those observed during ice storage, though no significant differences were observed between the muscles iced and stored at $-2^{\circ} \mathrm{C}$. During storage at $-3^{\circ} \mathrm{C}$, no appreciable amount of trimethylamine nitrogen was detected, initial spoilage of the fish being greatly reduced. The $\mathrm{K}$ value of fish muscle stored at $-3^{\circ} \mathrm{C}$ reached $20 \%$ after 2 weeks, whereas that of iced muscle reached $58 \%$ in 5 days.

The possibility that nucleic acids in fish muscle might be broken down to their mononucleotide constituents during ice storage or storage at $-3{ }^{\circ} \mathrm{C}$ was almost negligible as far as could be determined colorimetrically with the phloroglucinol reaction. However, degradation of nucleic acid molecules in iced muscle was indicated by the results of chromatography on methylated albumin kieselgur, whereas the degradation was reduced noticeably in muscle stored at $-3^{\circ} \mathrm{C}$.

From the present results with sea bass, storage by partial freezing at $-3^{\circ} \mathrm{C}$ seems to be effective as a means of preserving fish freshness when storage must be prolonged beyond the storage life of iced fish.
\end{abstract}

In the Japanese fisheries, icing and freezing have generally been used as a means of preserving freshness of fish during the storage in fishing vessels after catch. Freezing in particular has extensively been used in pelagic fishery such as tuna lining and skipjack purse seining, but it seems that freezing is not necessarily useful to fish caught by trawlers. SHIMIzU" noticed that the extractability of myosin fraction and the "Kamaboko" forming ability of muscle of demersal fish such as white croaker, lizard fish and round nose flounder decreased more readily compared to those of pelagic fish such as sailfish and yellowtail during frozen storage. Considering these facts, it is understandable that ice storage method has been adopted as a means of preserving freshness of fish caught by trawlers. However, the authors ${ }^{2,3}$ have pointed out that it is difficult to prolong

*1 Contribution from Tokai Reg. Fish. Res. Lab., B 595

*2 Tokai Reg. Fish. Res. Lab., Kachidoki 5-5-1, Chuo-ku, Tokyo 104. （内山 均 - 加藤 登：東 海区水産研究所)

Abbreviations used: ATP, ADP, and AMP; adnosine 5'-tri-, di-, and mono-phosphate, respectively, IMP; inosine 5'-monophosphate, HxR; inosine, Hx; hypoxanthine, TMA-N; trimethylamine nitrogen, s-RNA; transfer RNA, r-RNA; ribosomal RNA. 
the storage life of iced fish from the viewpoint of changes in the post-mortem autodegradation of muscle ATP and its related compounds and also bacterial decomposition products in fish muscle during ice storage. For example, the authors"' noticed that even in the case of plaice or Japanese sea bream which is well known to be species whose rate of freshness-lowering is very slow, the limit of storage period of these species might be about 10 days, since $\mathrm{K}$ value, fish freshness estimation index, of both species reached around $20 \%$ in about 10 days of ice storage.

It has been expected, therefore, to establish a new method which is used for preserving freshness of fish for 2-3 weeks, in place of iced- and frozen storage, since this period seems to be long enough to keep freshness of fish in fishing vessels from the fact that the average operation period of the fishing vessels presently engaged in the Japanese coastal and offshore fisheries has been shortened to within 2-3 weeks by extensive improvements of the vessels.

TomLInson et al..$^{5}$ showed that partial freezing storage is useful for preventing the proteolysis (belly burn) in salmon flesh surrounding visceral cavity and the serious spoilage of flesh to be canned when storage was prolonged beyond a few days. Besides, superchilling of fish has been studied by several workers ${ }^{6,7)}$ to elucidate the relation between fish quality and denaturation of fish muscle protein. Nevertheless, in Japan, research works in this field have been done much insufficiently and fragmentally compared to those of icing and freezing. The present investigation was performed, using sea bass, to compare the two methods, icing and partially frozen storage, as a means of preserving freshness of fish.

To begin with, an attempt was made to examine the rate of post-mortem autodegradation of ATP, its related compounds and nucleic acids and also the changes in free amino acids and TMA-N during iced- and partially frozen storage. The results indicated that the partially frozen storage seems likely to be more effective for preserving freshness of fish than iced storage.

\section{Materials and Methods}

Material Living sea bass, Lateolabrax japonicus (CUVIER) were obtained at the Tokyo Central Wholesale Market. After being killed by cutting hindbrain, a portion of muscle was dissected for " 0 time" control from anterio-dorsal position, and the fish was divided into two halves, each of them being sealed tightly in a polyethylene bag; one of them was preserved in crushed ice and another held partially frozen in a storage solution whose temperature was maintained at $-2^{\circ}$ or $-3^{\circ} \pm 0.1^{\circ} \mathrm{C}$ by using an electronic low-temperature thermostat (IKEDA RIKA Co. Ltd.). As a storage solution, ethyleneglycolcontaining anti-freezing liquid for automobile was used. A portion of the sample muscle was removed for analysis after various periods of storage as indicated. 
Determination of TMA-N TMA-N in fish muscle was extracted with trichloroacetic acid and measured by the picrate method as modified by HASHIMOTO et al., ${ }^{8}$ in which potassium hydroxide was substituted for potassium carbonate used in the original method proposed by DYER et al. ${ }^{91}$

Measurement of free amino acids Free amino acids in fish muscle were extracted with $0.44 \mathrm{M}$ trichloroacetic acid, analyzed colorimetrically at $550 \mathrm{~m} \mu$ by using the reagent of Folin-Ciocalteu, ${ }^{10)}$ and expressed as $\mu \mathrm{g}$ per $\mathrm{g}$ muscle in terms of the equivalent amount of authentic tyrosine.

Measurement of ATP and its related compounds, and $\mathrm{K}$ value Prior to the fractionation of ATP and its related compounds, fish muscle was extracted with cold perchloric acid and neutralized to $\mathrm{pH} 6.4-7.0$ with potassium hydroxide solution. The neutralized extract was fractionated according to the procedure of continuous gradient column chromatography using $\mathrm{AG} \mathrm{1} \times 4,200-400$ mesh $\mathrm{Cl}^{-}$type and solutions of different concentrations of hydrochloric acid and sodium chloride as described in previous papers. ${ }^{11,12)}$

According to SAITo et al ${ }^{13)}$, as a fish freshness estimation index, $\mathrm{K}$ value was used which is the percentage of the sum of $\mathrm{HxR}$ and $\mathrm{Hx}$ to the total amount of ATP and its related compounds in fish muscle.

Analysis of nucleic acids in fish muscle RNA in fish muscle was fractionated by the procedure of SCHMIDT-TANNHAUSER as modified by HuCHISON et al. ${ }^{14}$, measured colorimetrically at $550 \mathrm{~m} \mu$ with phloroglucinol reaction, ${ }^{15)}$ and expressed as $\mathrm{mg}$ per $\mathrm{g}$ muscle. Extraction and fractionation of intact nucleic acids were performed as described previously. ${ }^{16}$ ) The method involves the extraction of nucleic acids from minced muscle with $50 \mathrm{~mm}$ acetate buffer solution, $\mathrm{pH} 6.4$, containing $0.1 \mathrm{mM} \mathrm{MgCl}_{2}, 0.5 \%$ sodium dodecyl sulfate, $20 \mu \mathrm{g} / \mathrm{ml}$ of potassium polyvinyl sulfate, bentonite and $80 \%$ phenol in a Waring blendor. The nucleic acids thus extracted were subjected to fractionation by methylated albumin kieselgur column chromatography.

\section{Results and Discussion}

It has generally been accepted that when fish muscle is slowly frozen water is for the most part crystallized in the temperature range between $-1^{\circ}$ and $-5^{\circ} \mathrm{C}$. The amount of ice crystals formed differs significantly by only a slight difference of temperature less than $1^{\circ} \mathrm{C}$. This range of temperature has been defined as the zone of maximum ice crystal formation, in which severe deterioration of quality of frozen fish occurs as a result of rupture of fish muscle cells by the large ice crystal formed due to slow freezing. In choosing the temperature to be adopted for keeping quality of fish, rupture of muscle cells must be minimized. Consequently, temperature to be adopted seems to be near a point at which crystallization of water commences in fish muscle. 
At first, the possibility that the proteolysis in fish muscle might be prevented by partially frozen storage at $-2^{\circ} \mathrm{C}$ and $-3^{\circ} \mathrm{C}$ was investigated in a preliminary examination.

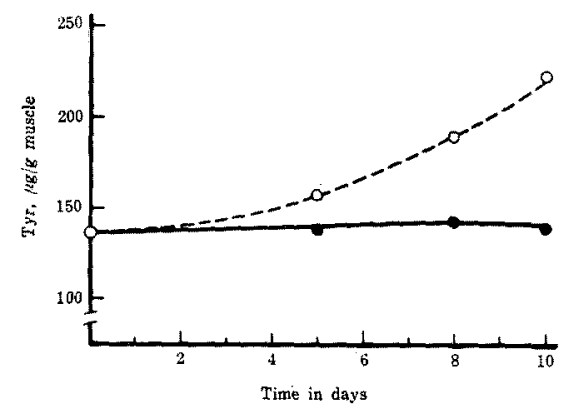

Fig. 1

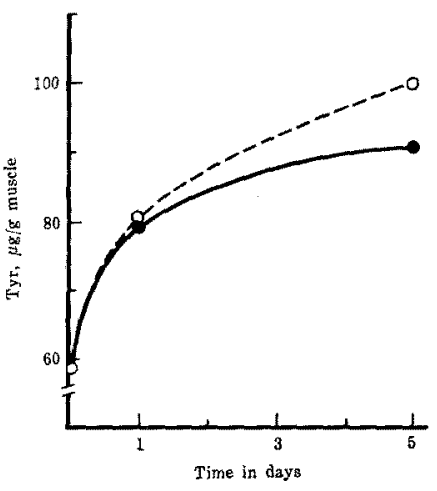

Fig. 2

Fig. 1. Changes in the amounts of free amino acids in sea bass muscle during iced storage and partially frozen storage at $-3^{\circ} \mathrm{C}$.

O-O-O, Iced; $-\longrightarrow$, at $-3^{\circ} \mathrm{C}$.

Fig. 2. Changes in the amounts of free amino acids in sea bass muscle during iced storage and partially frozen storage at $-2^{\circ} \mathrm{C}$.

$\mathrm{O}-\mathrm{O}-\mathrm{O}$, Iced; $-\mathrm{O}-2^{\circ} \mathrm{C}$.

Figs. 1 and 2 represent the changes of free amino acids in fish muscle during storage at $-3^{\circ}$ and $-2^{\circ} \mathrm{C}$ respectively, together with those of ice storage. In the storage at $-3^{\circ} \mathrm{C}$, fish muscle was somewhat stiffened about $10 \mathrm{hr}$ after the storage was started, indicating formation of small amount of ice crystal. The corresponding percentage of ice crystal formed in the muscle is 0 at $-2^{\circ} \mathrm{C}$ and $35 \%$ at $-3^{\circ} \mathrm{C}$ in the case of fresh marine fish as was quoted in ordinary technological books for frozen fish. A marked difference in preventing proteolysis was observed between iced and the $-3^{\circ} \mathrm{C}$ storage (Fig. 1), whereas the difference between iced and the $-2^{\circ} \mathrm{C}$ storage was not regarded as significant (Fig. 2) though amino acid content and its increasing rate differed from fish to fish. From these results it was assumed that $-3^{\circ} \mathrm{C}$ storage is more effective in preserving freshness of fish than $-2^{\circ} \mathrm{C}$ storage.

In this connection, the following test was made from the viewpoint of bacterial deterioration. Fig. 3 indicates the changes in amounts of TMA-N in fish muscle during iced storage and partially frozen storage at $-3^{\circ} \mathrm{C}$. In the case of storage at $-3^{\circ} \mathrm{C}$, TMA-N was increased very little, while in iced fish it began to increase remarkably 5 days after death. It was noteworthy that no appreciable amount of TMA was detected during storage at $-3^{\circ} \mathrm{C}$. That is, the spoilage which developed in iced fish was greatly reduced during partially frozen storage. 


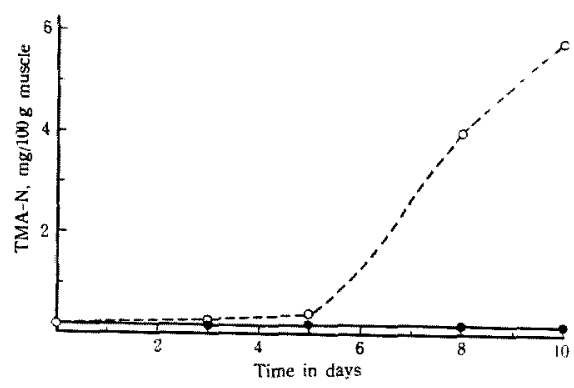

Fig. 3

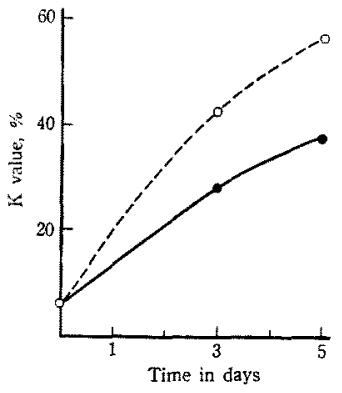

Fig. 4

Fig. 3. Changes in the amounts of TMA-N in sea bass muscle during iced storage and partially frozen storage at $-3^{\circ} \mathrm{C}$. O-O-O, Iced; $-\longrightarrow$, at $-3^{\circ} \mathrm{C}$.

Fig. 4. Changes in fish freshness estimation index, $\mathrm{K}$ value of sea bass muscle during iced storage and partially frozen storage at $-2^{\circ} \mathrm{C}$. O-O-O, Iced; $\longrightarrow-\infty$, at $-2^{\circ} \mathrm{C}$.

In the next place, the $\mathrm{K}$ values of fish during iced storage and partially frozen storage at $-2^{\circ} \mathrm{C}$ were compared, since $\mathrm{K}$ value is useful as a means of numerizing freshness of fish. The results of such experiments are presented in Fig. 4. The K value reached about $58 \%$ at ice temperature, and $38 \%$ at $-2{ }^{\circ} \mathrm{C}$, in 5 days (Fig. 4). As was already described in a previous paper, ${ }^{17)}$ the $\mathrm{K}$ values of good quality tuna, "Sashimi" and "Sushi-dane" or sliced raw meat for rice ball was foun to be around $20 \%$. Comparing this value with the results shown in Fig. 4 , it is clear that $-2^{\circ} \mathrm{C}$ storage can

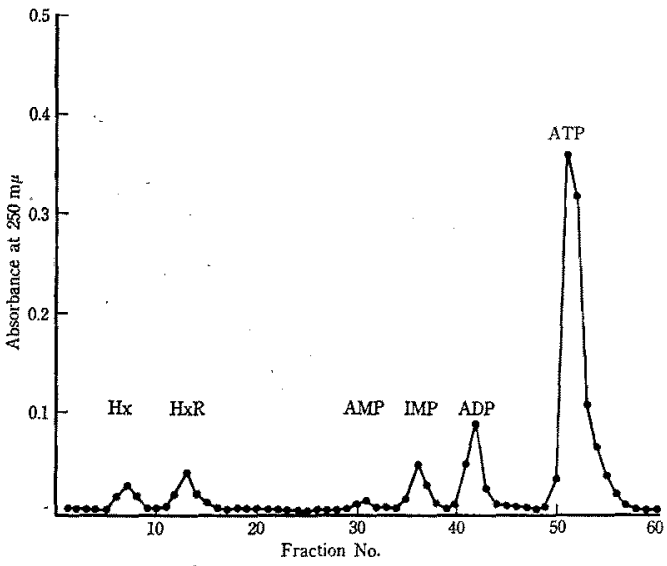

Fig. 5. Chromatographic pattern of the acidsoluble nucleotides and their related compounds in sea bass muscle taken immediately after being killed. Fraction volume: $2 \mathrm{ml} / \mathrm{Fr}$. for No. 1-25, $5 \mathrm{ml} / \mathrm{Fr}$. for No. 26-60. not be regarded useful for preserving freshness. Considering the above results of free amino acids and TMA-N also, the storage temperature should belowerd to $-3^{\circ} \mathrm{C}$. In order to elaborate this assumption, the changes in acid-soluble nucleotides and their related compounds in fish muscles iced and partially frozen stored at $-3^{\circ} \mathrm{C}$ for 10 days were compared by using column chromatography described above. Fractionation patterns of the compounds are indicated in Figs, 5, 6, and 7. In "0 time" control an overwhelmingly large 


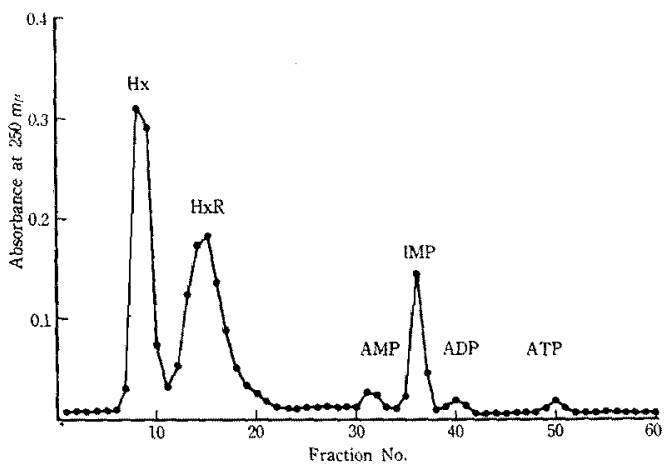

Fig. 6. Chromatographic pattern of the acidsoluble nucleotides and their related compounds in sea bass muscle iced for 10 days. Fraction volume: $2 \mathrm{ml} / \mathrm{Fr}$. for No. 1-25, $5 \mathrm{ml} / \mathrm{Fr}$. for No. $26-60$.

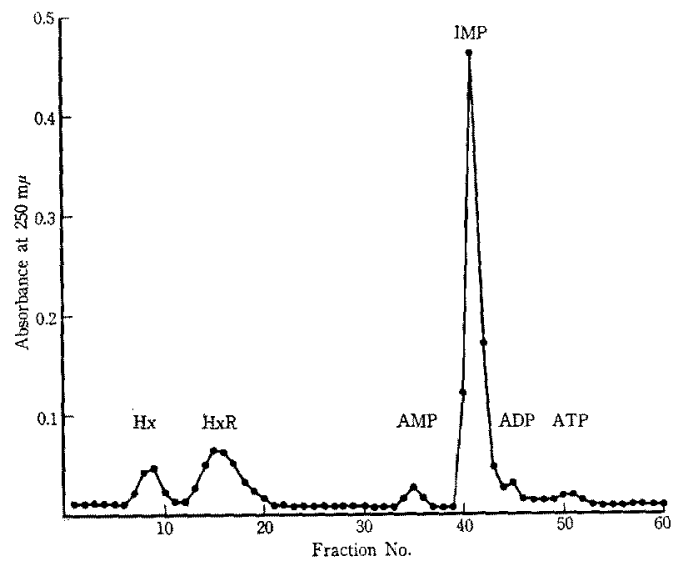

Fig. 7. Chromatographic pattern of the acidsoluble nucleotides and their related compounds in sea bass muscle stored partially frozen at $-3^{\circ} \mathrm{C}$ for 10 days. Fraction volume: $2 \mathrm{ml} / \mathrm{Fr}$. for No. $1-25,5 \mathrm{ml} / \mathrm{Fr}$. for No. 26-60. component of acid-soluble fraction was eluted between fractions 49-59. As the absorption ratio of $250 \mathrm{~m} \mu$ to $260 \mathrm{~m} \mu(0.85)$ of the fraction was in agreement with that expected for that of ATP, the large component observed was identified as ATP. In the fractionation profile from the muscle iced for 10 days, 3 components were eluted and identified as $\mathrm{Hx}, \mathrm{HxR}$ and IMP from ultraviolet absorption ratio mentioned above $(250 \mathrm{~m} \mu / 260 \mathrm{~m} \mu ; 1.45,1.68$ and 1.65 , respectively), showing marked post-mortem autodegradation of ATP. On the other hand, in muscle stored partially frozen at $-3^{\circ} \mathrm{C}$ for 10 days, peaks of $\mathrm{Hx}$ and HxR were small, and peak of IMP was eluted as a predominant component. Amounts of respective components and $K$ values calculated from Figs. 5, 6, and 7 are shown in Table 1. The changes in $\mathrm{K}$ value in the fish muscles iced and partially frozen stored at $-3^{\circ} \mathrm{C}$ for 2 weeks are shown in Fig. 8. From these results, it might be possible that the partially frozen storage at $-3^{\circ} \mathrm{C}$ isadopted, in place of ice

storage or frozen storage, as a means of preserving freshness of of fish for 1-2 weeks.

And further, examinations were carried out from the standpoint of nucleic acids degradation in fish muscle during storage.

The early work by $\mathrm{TARR}^{18 \%}$ indicated that an enzyme capable of degrading yeast RNA nearly completely, was present in the muscle of lingcod, Ophiodon elongatus and rockcod, Sebastodes sp. On the other hand, TomuInson et al ${ }^{19)}$ stated that no measurable change of nucleic acid content in lingcod muscle had been observed during iced storage, and noticed that the muscle nucleic acids themselves seemed to be protected or 
Table 1. Amounts of the acid-soluble nucleotides and their related compounds and fish freshness estimation index, $\mathrm{K}$ value of sea bass muscle taken immediately after being killed and after iced storage and partially frozen storage at $-3^{\circ} \mathrm{C}$ for 10 days.

\begin{tabular}{|c|c|c|c|c|c|c|c|c|}
\hline \multirow{2}{*}{ Muscle samples } & $\mathrm{Hx}$ & $\mathrm{H} \times \mathrm{R}$ & IMP & AMP & $\mathrm{ADP}$ & $\mathrm{ATP}$ & Total & \multirow{2}{*}{$\underset{\%}{K}$ value } \\
\hline & \multicolumn{7}{|c|}{$\mu$ moles $/ \mathrm{g}$ muscle } & \\
\hline At killing & 0.3 & 0.3 & 0.6 & 0.3 & 1.2 & 7.4 & 10.1 & 6 \\
\hline Iced & 2.7 & 2.9 & 1.8 & 0.6 & 0.3 & 0.3 & 8.6 & 65 \\
\hline $\begin{array}{l}\text { Partially frozen } \\
\text { at }-3^{\circ} \mathrm{C}\end{array}$ & 0.5 & 1.1 & 6.5 & 0.5 & 0.5 & 0.4 & 9.5 & 17 \\
\hline
\end{tabular}

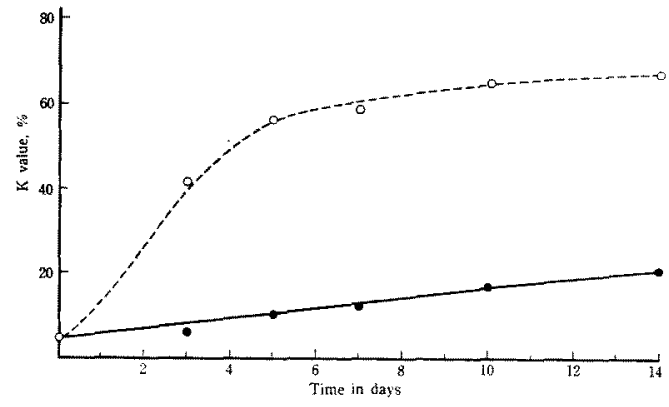

Fig. 8

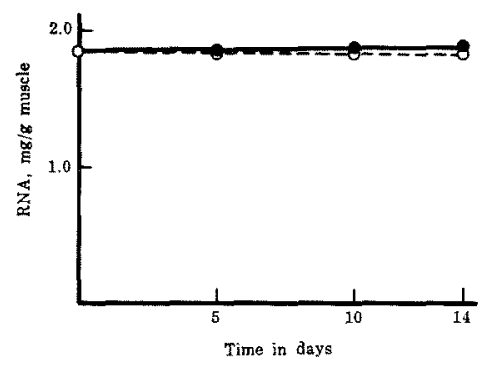

Fig. 9

Fig. 8. Changes in fish freshness estimation index, $K$ value of sea bass muscle during iced storage and partially frozen storage at $-3^{\circ} \mathrm{C}$.

$$
\text { O-O-O, Iced; - at }-3^{\circ} \mathrm{C} \text {. }
$$

Fig. 9. Changes in amounts of RNA in sea bass muscle during iced storage and partially frozen storage at $-3^{\circ} \mathrm{C}$.

O-O-O, Iced; $-\rightarrow$, at $-3^{\circ} \mathrm{C}$.

masked by protein against the nuclease.

As will be noted in Fig. 9, the changes in amounts of RNA in the fish muscle during storage were nearly negligible as far as examined by colorimetrically with phloroglucinol reaction. However, it is quite likely that post-mortem deformation, not decomposition, of nucleic acids molecule takes place in the muscle. To examine this possibility, the following experiment was carried out by using a column chromatography.

KImURA et $a .^{201}$ noticed that nucleic acids in living cells can be extracted by the phenol method in native state with biochemical activities, and the extracted nucleic acids were fractionated into s-RNA, DNA and r-RNA by the column chromatography on methylated albumin kieselgur. Based on these facts, the authors extracted nucleic acids from muscle taken from living fish by using the phenol method slightly modified. Fractionation profile of s-RNA, DNA and r-RNA on methylated albumin kieselgur column chromatography was identical with that of the nucleic acids prepared from living cells of Escherichia coli B as indicated in Figs. 10 and 11. From these results, the nucleic acids 
thus extracted fromthe muscle were presumed to be native or undegraded. However, when the phenol extraction procedure was performed without nuclease inhibitors such as bentonite and polyvinyl sulfate as described in a previous report, ${ }^{16}$ ) significant degradation of the nucleic acids occurred; peaks of 3 nucleic acids were noticeably smaller and broader,

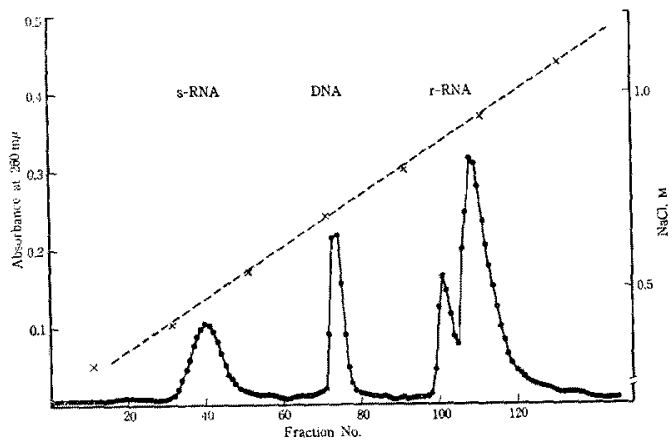

Fig. 10. Chromatographic profile on the methylated albumin kieselgur column of nucleic acids from sea bass muscle taken immediately after being killed.

$x-x--x, \mathrm{NaCl}$ concentration;

Absrobance at $260 \mathrm{~m} \mu$.

Fraction volume: $5 \mathrm{ml} / \mathrm{Fr}$.

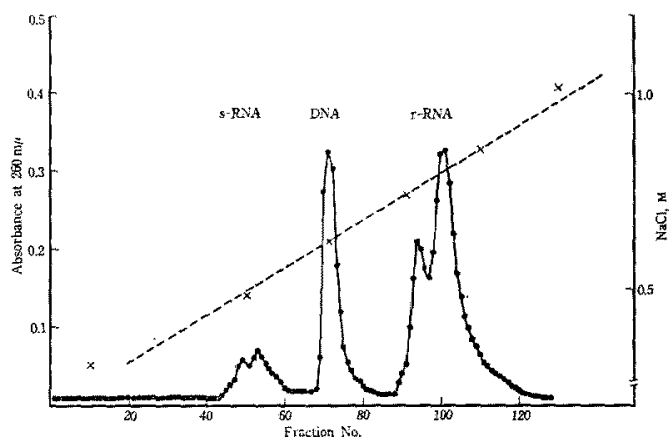

Fig. 11. Chromatographic profile on the methylated albumin kieselgur column of nucleic acids from Escherichia coli $\mathrm{B}$.

$x--x-x, \mathrm{NaCl}$ concentration;

Absorbance at $260 \mathrm{~m} \mu$.

Fraction volume: $5 \mathrm{ml} / \mathrm{Fr}$. andtended to be eluted into lower concentrations in the gradient of sodium chloride, evidently showing marked deformation of the nucleic acid molecules.

The profiles of the chromatogram of the nucleic acids from muscles iced and stored partially frozen at $-3^{\circ} \mathrm{C}$ for 2 weeks are presented in Figs. 12 and 13, respectively. In the case of ice storage, the 3 peaks of s-RNA DNA and r-RNA were smaller and broader, and eluted in lower sodium chloride concentrations in the gradient compared with "0 time" control, but in the case of the partially frozen storage at $-3^{\circ} \mathrm{C}$ this tendency was reduced evidently. From these findings, the deformation of the nucleic acids in the muscle during partially frozen storage at $-3^{\circ} \mathrm{C}$ was assumed to occur to a less extent than that of iced fish.

The results obtained in the present experiments have led us to the conclusion that as a means of preserving freshness of fish, the usefulness of partially frozen storage at

$-3^{\circ} \mathrm{C}$ can not be denied. However, these results are contradictory with the well accepted theor $y^{21)}$ that the denaturation of fish muscle protein proceeds remarkably in the temperature zone of maximum ice crystal formation when frozen slowly. Accordingly, it is obvious that further work must be done to ascertain in detail the relationship between the mode of denaturation of fish muscle protein and changes in freshness of fish during 


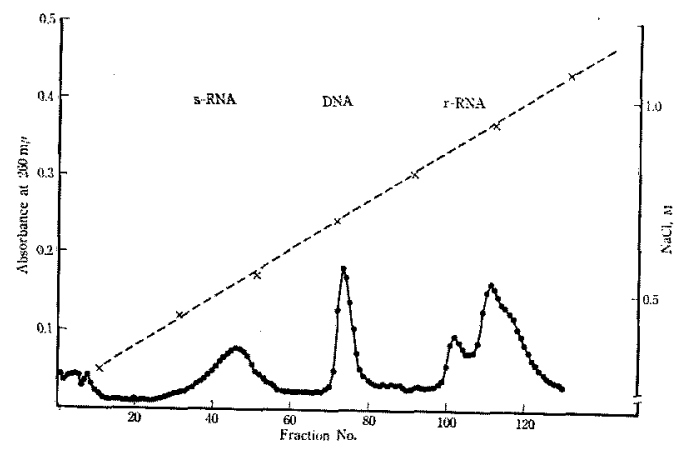

Fig. 12. Chromatographic profile on the methylated albumin kieselgur column of nucleic acids from; sea bass muscle iced for 2 weeks.

$x-\cdots--\lambda, \mathrm{NaCl}$ concentration; - Absorbance at $260 \mathrm{~m} \mu$.

Fraction:volume: $5 \mathrm{ml} / \mathrm{Fr}$.

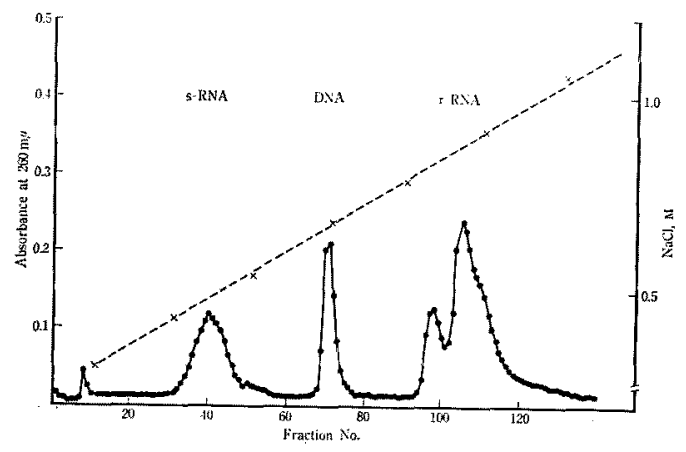

Fig. 13. . Chromatographic profile on the methylated albumin kieselgur column of nucleic acids from sea bass muscle stored partially frozen at $-3^{\circ} \mathrm{C}$ for 2 weeks. $x--x-x, \mathrm{NaCl}$ concentration; - Absorbance at $260 \mathrm{~m} \mu$. Fraction volume: $5 \mathrm{ml} / \mathrm{Fr}$.

the partially frozen storage. A study concerning this problem is under way.

\section{Acknowledgement}

The authors wish to express their thanks to Mr. Shigeo EHIRA, Tokai Reg. Fish. Res. Lab. for his valuable discussions given in the course of the present study.

\section{References}

1) U. Simzu: J. Fd. Sci. Technol., 16, 529-538 (1969).

2) H. UChiYama T. SuzukI, S. EhrRa, and E. Noguchi: This Bull., 32, 280-285 (1966).

3) H. UCHYYMA and S. EHIRA: ibid., 36, 977-992 (A Review) (1970).

4) S. EHIRA and H. UCHIYAMA: ibid., 40, 479-487 (1974).

5) N. Tomlinson, S. E. Geiger, W. W. Kay, J. Uthe, and S. W. Roach: J. Fish. Res. Bd. Canada, 22, 955-968 (1965). 
6) R. M. Love and M. K. Elerian: J. Sci. Fd. Agric., 15, 805-809 (1964).

7) R. M. Love: This Bull., 33, 746-752 (1967).

8) Y. HASHMOTO and T. OKATCHr: ibid., 23 269-272 (1957).

9) W. J. Dyer and Y. A. Mounsey: J. Fish. Res. Bd. Canada, 6, 359-367 (1945).

10) R. B. HAwk, B. L. OSER, and W. H. Summerson: in "Pract. Physiol. Chem." McGraw-Hill book Co., New York, 1947, pp. 138.

11) S. Ehira, H. Uchiyama, F. Uda, and H. Matsumiya: This Bull., 36, 491-496 (1970).

12) N. Kato, H. Uchryama, and F. UdA: ibid., 39, 1039-1044 (1973).

13) T. Saito, K. ARai, and M. Matsuyoshi: ibid., 24, 749-750 (1959).

14) W. C. Huchuson and H. N. Munro: Analyst, 86, 768-813 (1961).

15) Z. Dische and E. Borenfreund: Biochim. Biophys. Acta, 23, 639-642 (1957).

16) H. UCHIYAMA, S. EhIRA, and T. TsuchiYa: This Bull., 36, 74-82 (1970).

17) H. Uchiyama, S. EhrRa, H. Kobayashi, and W. Shimizu: ibid., 36, 177-187 (1970),

18) H. L. A. TARR: Food Technol., 8, 15-19 (1954).

19) N. Tominson and V. M. Creelman: J. Fish. Res. Bd. Canada, 17, 603-606 (1960).

20) K. Kimura, J. Tomoda, and A. Shibatani: Biochim. Biophys. Acta, 108, 540-550 (1965).

21) S. WATARI: in "Suisan handbook" (Fisheries Handbook) (ed. by M. UDA et al.) Toyo Keizai Shinpoosha, Tokyo, 1962, pp. 548-553. 